\title{
A Science of Nature, a Science of Crime: The Reception and Embedding of Positivist Criminology in Sweden
}

Anders Pedersson

\section{OpenEdition}

\section{Journals}

Electronic version

URL: http://journals.openedition.org/chs/2295

DOI: $10.4000 /$ chs.2295

ISSN: 1663-4837

\section{Publisher}

Librairie Droz

\section{Printed version}

Date of publication: 31 December 2018

Number of pages: 63-81

ISSN: $1422-0857$

\section{Electronic reference}

Anders Pedersson, "A Science of Nature, a Science of Crime: The Reception and Embedding of

Positivist Criminology in Sweden", Crime, Histoire \& Sociétés / Crime, History \& Societies [Online], vol. 22,

$n^{\circ} 2$ | 2018, Online since 31 December 2020, connection on 13 April 2021. URL: http://

journals.openedition.org/chs/2295 ; DOl: https://doi.org/10.4000/chs.2295

\section{This text was automatically generated on 13 April 2021}

(C) Droz 


\section{A Science of Nature, a Science of Crime: The Reception and Embedding of Positivist Criminology in Sweden}

Anders Pedersson

\section{Introduction}

1 This article analyses how the criminology of the Positivist school - Cesare Lombroso's school - was received and embedded in late nineteenth-century Sweden. ${ }^{1}$ It contends that the new science of crime was implanted in a broad cultural and political context. That means not only that a narrow scientific discussion was (to a large extent) determined by social conditions, but also that the ideas and findings of criminal anthropology and criminal psychology were in fact discussed by a range of actors in public and popular forums as well as in professional communities. Overall, the article contends that the mobilizing of positivist criminology in popular and political discourse can be seen a precondition for its establishment in medicine and in law.

2 After outlining the related contexts and theoretical framework, the article will first analyze popular and scholarly debates on criminology in late nineteenth-century Sweden. In the analysis of popular discussion, a sample of articles in the Swedish daily press will be used. The intention is not to discuss every article relating to positivist criminology, but rather to illustrate and examine a range of possible positions in the reception of a science of crime. Popular discussion of criminology will then be compared to how the topic was addressed in scholarly journals and books. Finally, the analysis will conclude with a brief discussion of the impact of the Positivist school on Swedish criminology and penal policy in the twentieth century. 


\section{The locality and transition of knowledge}

3 In the fields of the history of science and intellectual history, it has been established for decades that knowledge is locally produced. Whether conceptualized as "situated knowledge" or "local knowledge" the prevalent view is that knowledge, reason and truth are determined by the geographically local circumstances under which they are conceived. ${ }^{2}$ A stronger proposition states that it is not only the genesis that is determined by the place of birth but that this locality also defines the character of knowledge. As Jouni-Matti Kuukkanen points out, in this view "location not only shapes or influences scientific practice, it leaves a permanent imprint and can be used to explain the external manifestations of science". ${ }^{3}$ As such, every scientific idea is in a sense inseparable from its place of birth.

The emergence of the criminology of Lombroso can be analyzed from this perspective. Although he connected to broad European intellectual currents (Darwin's theory of evolution, the myth of degeneration, racism, Eurocentric anthropology, and so on), research has also shown how much the birth of criminal anthropology relied on a specific Italian cultural, political and social context. Social upheaval, conflict between the north and the south, and political turmoil played significant roles in the birth of criminal anthropology. ${ }^{4}$

5 Thus, when analyzing the embedding of criminal anthropology in late nineteenthcentury Sweden, a key question has to be how something, the existence and character of which is conditioned by local circumstances, can move from one context to another (as it obviously did). ${ }^{5}$ It is true that the original establishment of a Positivist school of criminology was determined by the late nineteenth-century Italian context. But it is equally as true that its doctrine spread around the world. The apparent paradox can be phrased - as Melossi et al. aptly do - as "how can something that is in significant ways embedded, situated, and locally produced also travel?"6 James A. Secord has tried to reformulate the whole problematic of the production of knowledge and to make this travel the fundamental aspect of the history of science. He proposes that we replace the perspective of "science in context" with that of "knowledge in transit". He stresses that such a perspective does not disqualify investigations of the locality of knowledge: "It's not so much a question of seeing how knowledge transcends the local circumstances of its production but instead of seeing how every local situation has within it connections with and possibilities for interaction with other settings." 7

6 The question to be addressed here then is: How did Sweden of the late nineteenth century connect to broader international discussion of science and crime? Representations of and opinions about crime and criminals - criminology being one way to produce such representations - are always the result of broader and deeper cultural, social and political concerns. ${ }^{8}$ This article will therefore approach the question of the reception and embedding of positivist criminology in Sweden from the point of view that science - especially of the kind we nowadays like to call social science - is implanted in new situations by connecting to a range of discourses, thereby becoming a "reality", not just for a few experts but in a wider public domain. Before the science of crime became useful in policy and administration, it was made obvious for a much larger audience. 


\section{The international context from a Swedish perspective}

7 In 1876 the first edition of Cesare Lombroso's L'uomo delinquente was published. In that book Lombroso aimed to prove that criminals had different psychological and bodily characteristics to those of ordinary law-abiding citizens. Lombroso suggested that there was such a thing as a "born criminal", an evolutionary throwback, an individual representing an earlier stage in the development of the human species. A theory like that challenged the classical perspective in penal law. The existence of the criminal as a positive phenomenon implied that crime was not an act in defiance of the law, but represented the asocial and dangerous behavior of certain kinds of individuals. The crime was not the result of a choice by the criminal but was determined by factors outside his or her control. This in turn had consequences for how the role of penal law was understood. It should not, in the light of a science like that of Lombroso, administer punishment according to the crime committed, as it did in classical jurisprudence and liberal penal law. Rather it should take the measures needed to protect society, decided after an examination of the individual's psychological and bodily characteristics. The punishment should fit the criminal, not the crime. ${ }^{9}$

8 A whole new movement then formed around Lombroso. This group, sometimes known as the Positivist school of criminology, consisted of anthropologists, medical doctors, lawyers, sociologists and police officials. They commenced a long series of investigations and the scholarly work was channeled mainly through the journal Archivio di psichiatria, antropologia criminale e scienze penali. Lombroso was the spiritual leader of the school, but was controversial and chiefly dedicated to research on "his" criminals. The shaping of the criminological discipline therefore often taken forward by others. Among Lombroso's many followers, the lawyers Raffaele Garofalo and Enrico Ferri stood out. In the late 1800 s they, as much as Lombroso, would shape the ideology and program of Italian criminology. ${ }^{10}$

9 Lombroso and his school soon found themselves under heavy critique. The most forceful opposition came from French anthropologists, lawyers and sociologists. In several instances, not least at the famous International Congresses for Criminal Anthropology - taking place seven times up until the First World War - they turned on what they perceived as the biological determinism at the core of Lombroso's theory. They did not oppose biological explanation of criminal behavior. They criticized the positivist school for the theories of atavism and the born criminal, but acknowledged that inherited mental disposition could play a part in the creation of criminals. In a broader European context the science of Lombroso, therefore, soon became one of many competing perspectives on the criminal, taking center stage because of its bold scientific claims and the radical political consequences of criminal anthropology. ${ }^{11}$

At the same time as conflict arose between competing scientific traditions, the Internationale Kriminalistische Vereinigung (IKV - International Union of Penal Law) was established. Created in 1888, this association of criminalists was not a scientific society, but rather a reform movement for penal policy. They championed a penal law with the main purpose of protecting society through the prevention, incapacitation and rehabilitation of the individual lawbreaker. If discussions at successive International Congresses of Criminal Anthropology focused on asking and answering scientific questions about the causes of crime, the IKV spent its time discussing changes to penal law deemed necessary in relation to the existing politics and constitutions of 
the nations of Europe. Where the criminologists of the positivist school believed that scientific knowledge should determine the reform of penal law, the IKV admitted to problems relating, for example, to legal certainty and general prevention that a truly criminologically-determined penal law implied. ${ }^{12}$

Even though internationally it was a moderating force, the IKV became important for the growth and character of criminology, not least in northern Europe. First, it shared the positivist school's critique of classical penal law. Second, in many of its core statements the IKV relied on criminological knowledge. Third, the philosophical and practical implications of the reforms proposed by the IKV offered an important context for criminological rationality. In the statutes of the IKV the purpose of the association was to combat crime as a social phenomenon, and to ensure that the results of anthropological and sociological research were to be taken into consideration by scientific and lawmaking bodies. ${ }^{13}$

The founder and leader of the IKV was German professor of penal law, Franz von Liszt. He was not an empirical scientist in the Lombrosian model but formulated theories of criminological relevance. He pleaded first and foremost that penal law should differentiate between different types of criminals and that the criminal should be examined with respect to both their biological constitution and environment. It was through intertwining with the pragmatist reform ideas of the IKV and von Liszt that the criminology of the positivist school would make its way into Swedish penal policy and penal law in due course. ${ }^{14}$

\section{Sweden at the end of the 1800s}

The late nineteenth-century Sweden which received the continental discourse on criminal anthropology was, as were many others at the time, a society in transition. New economic, social and political structures created a whole new set of problems. Via the processes of proletarization, industrialization and urbanization, old ways of governing were being challenged. ${ }^{15}$ Politics during the second half of the nineteenth century had gained a new dimension with the growing importance of the public sphere and considerable parliamentary reform (when the Parliament of the Estates was replaced by a parliament with two chambers with its members chosen in national elections). Existing and new political factions mobilized around what were perceived as urgent social and economic issues. The situation was further complicated by the emergence of an organized workers' movement. The Social Democratic Party and the socialist trade unions were formed in the last decades of the century. ${ }^{16}$ The conservative establishment now not only had to worry about bourgeois liberal political opponents and an unruly underclass but also a new enemy who wanted to overthrow the old order.

14 These political struggles, in Sweden as in the rest of Europe, were paralleled by the process of natural scientific thinking making its way into political discourse: knowledge of the world meant mastery of the world. The likes of Darwin and Haeckel had described the laws and conditions for the history of creation and for the origin of the species. There were many who tried to transfer those ideas of adaptation, heritage, development and struggle to man and society. ${ }^{17}$ Through the work of Herbert Spencer these notions further laid the foundation for a certain kind of liberal thought. On the political left, Marxism merged with Darwinism to create a scientistic socialism (Enrico 
Ferri of the positivist school was among those who elaborated such ideas). ${ }^{18}$ It was in this broader context of the arrival of natural science as the solution to social problems that positivist criminology made its way through Europe, reaching Sweden in the mid-1880s.

Positivist criminology was not received in Sweden because of its usefulness for penal policy alone. Rather, it was thanks to the dynamics created by it being embedded in different spheres that criminology in due time would become a vital tool for the state's approach to criminal justice policy. The Swedish legal and political establishment in the late nineteenth century was particularly patriarchal and conservative. It carried with it an institutional inertia, making it hard for radical ideas to be accepted. Instead the daily press and popular magazines, pillars of the public sphere, were instrumental in allowing criminal anthropology and the positivist school to be received outside the legal and political institutions.

The daily press was one of the main forums in which crime was presented as a growing problem and as a problem which needed to be solved. In newspapers all over Sweden there were reports on heinous crimes, on trials which drew special attention and about the state's efforts to curb the criminal problem. Side by side with current issues, from the 1880s onwards the reader was also informed of the new science of crime, originating in Italy, which was beginning to be recognized around the world. ${ }^{19}$ From that perspective, the relevance of positivist criminology could be seen as rather obvious. Therefore this analysis begins with the discussion of international criminology in the Swedish press and popular magazines.

\section{International congresses as focal points}

The International Congress of Criminal Anthropology, which took place seven times between 1885 and 1911, was important for the representation of a new science of crime in the public sphere. Martine Kaluszynski characterizes the congress as a place for the establishment of a discipline, a place for the dissemination of knowledge and a place for power struggles, mainly between doctors and lawyers..$^{20}$ These congresses were but a few in a plethora of different scientific and political meetings taking place around the world during the late nineteenth century, which enabled not only knowledge, but also culture, to travel across and beyond national borders. ${ }^{21}$

The reporting of these events in the Swedish press in the last decades of the nineteenth century was multifaceted. It went into detail about the scientific theories and their political consequences. As illustrated by articles appearing in the Svenska Dagladet in August 1892, the program of the positivist school was presented in seven paragraphs. All the main actors were named: Lombroso, Ferri, Lacassange, Benedikt, Kraeplin, and so on. The conflicts between the Italian and the French school were given extensive coverage. The Swedish readers learnt of Lacassagne's forceful critique of Lombroso, which stressed the importance of the social causes of crime. Reports portrayed a range of different critiques of Lombroso, but still often concluded that the lasting impression of the congresses was one of unity. ${ }^{22} \mathrm{~A}$ reoccurring trope in the reporting from inside and around the congresses was the role given to Lombroso. He was portrayed as a genius, the creator of a new science. But he was also perceived as a careless and audacious researcher, who made far too much of his findings. ${ }^{23}$ 
However, Swedish readers, through the reporting from the congresses, were not only presented with dry, "scientific" facts. The reporting also thrived on notions of performance, spectacle and culture. In the late nineteenth century a culture of visuality grew in modern societies. Things should be seen. The world was apprehended by the very act of watching and perceiving. ${ }^{24}$ Pictures, photos, exhibitions, maps, graphical diagrams and cinematography gained importance for culture and science. When the first International Congress of Criminal Anthropology took place, in Rome in 1885, one of Sweden's biggest dailies did not publish any report from the congress as such, but instead covered the exhibition taking place in connection with it. Ahead of the congress, readers were told that there were to be graphical charts, thousands of photos, hundreds of brains, skulls and masks on display and afterwards this event was confirmed and further reported on. ${ }^{25}$ In 1889 in Paris the press, represented by the famous anthropologist Gustaf Retzius, delivered graphic accounts of a demonstration performed by the founder of criminal anthropometrics, Alphonse Bertilion, in which a recently arrested criminal was examined, measured and registered in front of an impressed audience. ${ }^{26}$ In other notices the reporter focused on the milieu surrounding the congress: the venue, the political authorities who attended the receptions, and the elegance. The reports focused as much on the entertainment value of such occasions as on the proceedings of the scientific congress. Thus, criminal anthropology was not related to dingy prison cells or silent rooms of parliamentary committees. It was connected to the Exposition Universelle, the mighty halls of university buildings and to the metropolises of Europe. ${ }^{27}$

Even if they were not as glamourous as the congresses for criminal anthropology the meetings of the IKV also drew attention in the Swedish press. Some of the reporting was sober, recounting in detail the content of the proceedings. ${ }^{28}$ Some newspapers, especially on the political left, did place the IKV meetings in a broader context. A liberal newspaper concluded that the reforms proposed by the IKV were the way forward and a product of the most cultivated and educated minds. ${ }^{29} \mathrm{~A}$ socialist newspaper took its argument one step further, stating that the congress was heralding a new era in which moralistic and religious argument would be replaced by scientific reasoning. The congress was deemed to be "a beautiful expression of the modern, more human, principles of law". ${ }^{30}$

21 It is thus clear that a large part of the reporting around the different congresses established criminology and the new theories of penal law not just as scientific discourse, but also as high culture, progress, and spectacle. In short, for a Swedish lay audience they were artifacts and indicators of modern times. The particular discourse of criminal anthropology thereby could find resonance in broad segment of Swedish society.

\section{Public criminological discourse}

The new science of the criminal in modern societies was not only discussed in relation to international congresses, though. In the press and in other public forums it was discussed in some detail in relation to a range of topics including recent crimes, ongoing trials, political events, the publication of books, and lawmaking in Sweden or other Nordic countries. The frame of positivist criminological discourse was thus outlined in different contexts. Popular discussion of criminological theory was perhaps 
somewhat simplified, but it gave the readers insights into the main tenets of the new science.

In portrayals of criminal anthropology in Swedish public forums it became clear that the foundation of Lombroso's science was the otherness of the criminal. It was presented as the positivist school's main finding that criminality could only be understood through the criminal, not the crime. ${ }^{31}$ When this had been established, the question of what made the criminal differ from the normal person was raised. It was not that the former had committed a crime and the latter had not. Readers understood that there was a cause behind the criminal act that defined the criminal. When in public discussion the argument had gone that far, the question of the characteristics of a criminal often arose. Here a distinction was frequently made between individual and social causes, but as regards individual causes distinctions were also made between anatomical and psychological characteristics. ${ }^{32}$ The reporting of the conflicting views in the international community on the causes of crime recurred so frequently and prominently that it is tempting to say that this very conflict was a condition for criminological discourse to be established among the Swedish public.

The criminological project, which was starting to gain momentum in Europe, was thereby not articulated as the production of truth about crime and criminals, but as a truth-seeking project. And that project was connected to a range of more or less famous legal or scientific individual actors, making the public discourse of criminology in many ways a discussion of the virtues and fallacies of different celebrities. Center stage in such a discussion was, of course, taken by Cesare Lombroso.

\section{Lombroso as symbol}

Lombroso was not the only representative of criminology, or even of criminal anthropology, in the Swedish discussions, but his scientific achievement was central to how the new teachings were understood. In the Swedish press and popular publications both Swedish and foreign actors criticized the Italian and his school. He was said to be sloppy and that evidence pointed in a different direction to that of Lombroso's biologically deterministic conclusions. ${ }^{33}$ But it must be stressed that this did not diminish the importance of Lombroso in discussions of criminology.

Lombroso was the symbol of the new science. For better or for worse, it was his theories that for many years were the foundation for criminological discussion in the public sphere in Sweden. It was about him that reports and analyses were delivered. If others from the positivist school were mentioned it was often in relation to its leader; when French criminologist were mentioned it was as opponents of Lombroso and when the IKV were discussed, in many cases it were presented as a pragmatic alternative to Lombroso and his theories. Lombroso was someone to relate to whether one was his friend or foe.

Lombroso and his school did not only provide knowledge of the criminal and the theories of crime. The science of the Italian psychiatrist was perceived as so much more, capturing the Zeitgeist of late nineteenth-century Sweden. The members of the positivist school and their endeavors made their way into the popular forums of Sweden. Sometimes there was just a little notice (Enrico Ferri sides with the socialists. Lombroso discusses the anthropology of the kiss. Can the positivist school diagnose a 
criminal crocodile?). ${ }^{34}$ Sometimes there were longer texts discussing at length the new science and its protagonists (What happens to free will? How should penal law be arranged? Has Lombroso really attended a séance?). ${ }^{35}$ Sometimes texts by the members of the positivist school themselves were published. In a radical journal the reader could find Lombroso talking about religion and crime, Ferri discussing the tenets of the positivist school and Scipio Sighele investigating the topic of "modern criminals". ${ }^{36}$

The relevance as well as the political and cultural value of criminal anthropology was highlighted even more by the obsession with crime and wickedness in contemporary realist and naturalist fiction. Leading Swedish and internationally renowned writers, such as August Strindberg and Ola Hansson, sometimes portrayed themselves as scientists of a kind. They expressed their fascination for criminal anthropology and articulated a way of understanding crime through determinism and the criminal by his otherness. Texts which in fictional form presented the basic assumptions and conclusions of the new science of crime were written years before scholarly work on the subject was produced in Sweden. ${ }^{37}$

Culturally then, Lombroso was à la mode, the flavor of the day. Everyone in the intellectual sphere in Sweden at the time knew of him and his theories. ${ }^{38}$ And as in many other countries in Europe the discussion on Lombroso and his science in Sweden soon gained an obvious political dimension.

\section{A tool in political conflicts}

30 Culturally, criminal anthropology connected to a range of Swedish intellectual currents and was thereby also brought into the political conflicts of the day. The reception of the positivist school in Sweden during the late nineteenth century was part of a broader movement in which the natural sciences made their entrance into societal and political discourse. This was in practice a challenge against the ruling order. The Swedish state was to a large extent ruled by a caste of established public servants. They believed that they upheld the order of society by their honoring of heritage and tradition. They felt they earned their legitimacy through their common sense, loyalty and lived experience. With the arrival of scientific theories relating to society and the social order an alternative was set up which presented itself as impartial, drawing its conclusions from nothing but the careful study of reality. ${ }^{39}$ In this way positivist criminology was articulated as resistance and a tool for reform and opposition.

The positivist assumption that free will did not exist created a battlefield between the new and the old traditions. Lombroso and his school stunned part of the Swedish establishment through their flat-out denial of the existence of free will. Swedish conservatives saw this stance as a threat to society. If people did not believe that they had free will, all morals would crumble, conservatives thought. There would be no way to demand responsibility, the foundation of social control was deemed to be under attack. The philosopher and psychologist Frans von Schéele, for example, delivered a critique of Lombroso and his school in public lectures, held in both Stockholm and Gothenburg in the early 1890 s and later reported in the press, in which he stated that the individual's belief in free will was the precondition for every citizen to do his or her duty to society. ${ }^{40}$ Consequently, those Swedish radicals who supported the cause of positivist criminology saw the attack on the concept of free will as an attack on the 
crumbling pillars of an outmoded society which blamed the behavior of poor and vulnerable people on their bad character and dreadful morals. ${ }^{41}$

In effect, by the mid-1890s criminal anthropology, the science of Lombroso and his Scuola Positiva was established in the Swedish public sphere, on the one hand as a discourse on the criminal and his otherness and on the other hand as a symbol of a brave new world, as a harbinger of modernity and as a form of opposition to a conservative establishment. As such it connected to political conflicts as well as cultural sentiments and social struggles. The sections which follow will consider how Lombroso was received in scholarly circles, first by the medical doctors and then by legal scholars.

\section{Medical discourse}

As in the rest of the western world, by the end of the nineteenth century Swedish physicians increasingly presented themselves as authorities on social problems and social knowledge. Medical doctors were well represented in discussions of public hygiene and of the organization and reorganization of society. In the criminal court they filled a vital role in determining the mental state of the offender. Legal medicine and forensic psychiatry was the natural home for a scientific discourse on crime. ${ }^{42}$

Since at least the late eighteenth century the medical profession had been a part of the Swedish justice system. It was represented by forensic experts (investigating causes and times of death, etc.) and experts on mental illness. It had long been a tradition, and at the end of the eighteenth century it was codified, that an insane person could not be punished under Swedish penal law. Soon afterwards, the physician's role as an examiner of such criminals that the courts suspected of being insane was regulated. ${ }^{43}$

In the late 1800s the medical profession understood that there was a professional and scientific predicament for Swedish legal medicine. The medical expert was summoned by the court to evaluate whether the defendant was responsible for his or her act in full, in part or not at all. The doctors criticized the courts for not summoning them often enough, and, when they did, argued that the expert was tasked with pronouncing judgement on what was basically a legal concept - responsibility - not on the criminal as such. The doctors therefore understood themselves as working in the borderline between morality and science. Their object of inquiry was defined by lawmakers and the court's officials, and therefore arbitrary. It was only the method of investigation that was rigorous and based on the natural sciences. ${ }^{44}$ This would be amended by positivist criminology.

The positivist school was not mobilized in Swedish medicine because of the school's controversial positions and Lombroso's sensational theories. The role of positivist criminology would be to help articulate a science of crime as a natural science in Swedish medical discourse. It helped to bridge the gap between normativity and nature, between law and natural science. Positivist criminology supplied theoretical structure as well as scientific confidence.

The relation of the Swedish medical profession to Lombroso was ambivalent. No serious medical doctor would say that they believed in the theory of the born criminal. Lombroso was criticized for his overly bold conclusions and was shown to be wrong in fundamental aspects of his science. The clearest example of that was when the 
renowned physician Ludwig Wolff in a lecture which was later published in the medical journal Hygiea, showed how critical assessments from other scientists had dismantled, piece by piece, Lombroso's theory of the born criminal and of the atavist. ${ }^{45}$ None the less, Lombroso's name was frequently invoked in discussions on the biological causes of crime. In a medical thesis from 1895 the author, the psychiatrist and army physician Axel Johan Ekdahl, excused himself midway through a discussion on the heredity of low morality: "I know also that at first sight many see Lombroso's teaching in my argument", but that was certainly not the case, the author underlined. ${ }^{46}$ The need to keep the flamboyant father of modern criminology at arm's length was obvious. Another Swedish medical doctor, the psychiatrist Georg Schuldheis, conceded that one had to admit that the legacy of Lombroso's work was the knowledge that criminals were inferior, in both a physical and a psychological sense. But concerning the facts, the Italian psychiatrist was plain wrong, Schuldheis stressed. ${ }^{47}$ Thus, Lombroso was invoked, only to be expelled the next moment. Against this background it can be argued that the legacy of the positivist school of criminology in Sweden was form, not content. Put in another way, Lombroso's radical theories were an important impetus for the criminological project in Sweden, but they would not define this project when it moved forward.

What is striking - apart from how strong and recurrent the theme of invoking or refuting Lombroso was - is that it seems as if the medical doctors discussing criminal anthropology to some extent relied on a popular conception of the new and controversial science. It was seldom that Lombroso's theories were closely scrutinized by Swedish medical doctors, probably because they had met with such hard criticism in the press and popular journals even before they became a subject of medical discourse. ${ }^{48}$ Instead, the Swedish psychiatrists who tackled the subject of criminology brushed aside Lombroso to make way for a mobilization of those who were seen as real authorities: For Ekdahl and Schuldheis these authorities were German psychiatrists and psychologists, such as Kraepelin, Krafft-Ebing and Baer. ${ }^{49}$ The positivist school supplied the enthusiasm, passion and revelation. German medicine delivered the hard and reliable facts.

Swedish psychiatry would eventually create its central position in Swedish penal policy by proposing solutions to the institutional problems created by the shortcomings of the courts and the prison service. Through time, after the turn of the century, medical experts would come to help both in policy making and in the day-to-day work of dealing with asocial and criminal individuals in Sweden. It heralded the new regime of welfare in penal policy: some criminals should go to the reformatory; some should go to the mental hospital, some to the criminal asylum, and some to labour camps or other institutions. In many ways this practice relied on the insights of the positivist school. The punishment should no longer only fit the crime, but also the criminal. Assessment of guilt and responsibility should be complemented by an investigation of the individual's dangerousness. And if the psychiatric avant garde in Sweden had had its way, the rule of law would have been replaced by the rule of natural science. ${ }^{50}$ Such was the legacy of Lombroso. 


\section{The legal establishment}

For physicians, the relation between crime and natural science concerned the role of medicine in legal proceedings. For jurisprudence, positivist criminology challenged its basic theoretical assumptions and the rule of penal law. The new situation from the 1880s onwards could be boiled done to one very serious question: To what extent should science be allowed to determine the practice of legal scholars and officers of the court?

41 Mainstream lawyers did not shun positivist criminology because of professional rivalry with the doctors. Their objections were more fundamental and serious than that: the rule of law was seen to be challenged. In a system - such as that proposed by the positivist school - where punishment was to be meted out on the basis of the dangerousness of the individual and society's need for protection, the principle of legality as well as the principles of proportionality were rendered irrelevant. The defendant would have to rely on the arbitrariness of the scientific expert. The function of penal law as a general deterrent was also in danger due to the positivist school's narrow focus on the individual, legal scholars believed. ${ }^{51}$

One way to tackle the challenge from positivist criminology (successful for some time) was to ignore it altogether. It is illustrative of the lawyers' disregard for positivist criminology that it was not given much consideration in scholarly journals. A comparison between how the subject was treated in the daily press and popular journals and how it was discussed in legal journals shows that the interest from Swedish law scholars was strikingly limited, at least as discussed in their own circles. Instead they opted to treat the question of penal law from a sort of legal formalist perspective. The mainstream in Swedish jurisprudence belonged to the classical tradition where just punishment was a vital part and the legal subject was understood as a rational and calculating human being. Jurisprudence should mainly concern itself with the concepts and formulation of the law..$^{52}$ This endeavor was not challenged by positivist criminology, which had its focus on other perspectives of penal law.

Some lawyers acknowledged in public the value of positivist criminology. Fredrik Sundberg wrote a booklet under the title Om brott och brottslingar [On Crime and Criminals] in which he lauded Lombroso as the founder of a new science, and the judge Wilhelm Uppström was noted in the press as having tried to mobilize the discourse of criminal anthropology in the assessment of suspects in his court. ${ }^{53}$ Those were exceptions, though, but as positivist criminology became more and more anchored in public discourse the legal scholars had to at least acknowledge the existence of the new natural science of crime. In doing this it was often dismissed as irrelevant. Legal scholars could concede that the public could be interested in the knowledge that was produced by criminal anthropology and criminal psychology, but it was still not of interest to the jurisprudence of penal law. The scientific study of law should not take natural science into consideration. ${ }^{54}$

In hindsight we can see that these legal scholars, trying to protect the borders of their institutionalized study of law at the same time as the public and political relevance of the positivist school was growing, risked their position as authorities in the discussion on crime and punishment. The foremost example of that was Johan Hagströmer, professor of penal law at Uppsala University at the end of the nineteenth century. In his inaugural lecture he made clear that he would not take any interest in topics 
relating to criminology in his role as professor. Accordingly, Hagströmer's textbook on Swedish penal law published in the first decades of the twentieth century did not contain any references to neither the positivist school nor the IKV. But at that time the rest of society had become more aware of these doctrines and theories, and many saw Hagströmer as out of date..$^{55}$ And as the realities surrounding the act of a crime became more and more central in penal policy debates, medical doctors, psychologists and lawyers, prepared at least to listen to the theories and findings of the new science, took center stage.

Slowly the continental theories of penal law were taken up by many lawyers in Sweden. It was done through the legal scholars' own approach of invoking Lombroso only to reject him. The radical teachings of the positivist school of criminology could be acknowledged in part, then deemed as too radical, and finally replaced by a more moderate alternative. That alternative was the one supplied by the IKV. For some lawyers this association stood for a modern, in some ways radical, but not scientistic view of penal law and penal policy. Their understanding of crime and the criminal was similar to that of the positivist school. But where the Italians would not budge an inch from their stance that science should dictate punishment, the international union was pragmatic. They took into consideration the need for general prevention, the legitimacy of the justice system and the social effect of punishment. Swedish legal scholars saw those views of von Liszt and his allies as a viable way forward in reforming penal law and penal institutions. A new generation of Swedish professors of penal law, chiefly represented by Johan Thyrén at the University of Lund, would after the turn of the century take it upon themselves to bring Swedish jurisprudence in line with continental thinking, taking into consideration the individuality of the criminal, the assessment of dangerousness and the protection of society as guiding principles. They did so without walking down the radical path of the positivist school. ${ }^{56}$

In the 1890s and the early 1900s additions to the Swedish penal law of 1864 started to be made. Two of the reforms were laws for conditional sentencing and for juvenile detention. Both of these embodied ideas of individualization and differentiation in the handling of criminals. In the following decades even further reforms of that kind were put into practice. In the preparatory work on the legislation, Swedish legal scholars discussed the modern theories of crime. Drawing on the work of the IKV to walk the line between jurisprudence and natural sciences, to be able to take into consideration the reality of the criminal and society without being left to the mercy of the medical profession, the Swedish legal community in a way took a stance against the positivist school - or at least the kind of ideas they represented. ${ }^{57}$ Given the role of scientific antagonists, for reform-friendly legal scholars, Lombroso and his cadre were still a valuable enemy.

\section{Conclusion}

47 At the beginning of the twentieth century the positivist school of criminology and its program were firmly established in the Swedish public sphere, had been received and discussed by the medical profession, and had played a part in challenging traditional Swedish jurisprudence. The presence of positivist criminology was naturalized in the public sphere, making it a fact for medicine and law to relate to. 

by three perspectives on crime and its remedies: positivist criminology, the doctrine of the IKV, and the classical tradition. Conjectures would shift the emphasis: no single perspective could ever achieve dominance; they would keep each other in check. In the heyday of social engineering in the 1930s and 1940s, the logic of the positivist school would be at its highest peak. It gained influence not in the shape of Lombroso's spectacular theories but in the sober and consistent discussion of penal law provided by Ferri; rather than relying on radical and astonishing theories about the nature of the criminal, the law should be constructed to enhance individualization, differentiation and the protection of society. For distinguished Swedish reformers, thus, the catchphrases for a thoroughly rational penal policy were "social defense" and "social responsibility". This thinking greatly influenced the penal law reforms and the reforms of the prisons taking place in Sweden up to the end of the 1950s. ${ }^{58}$

By that time the picture of criminology had changed in the public sphere, in the press and in other areas of public discourse. Criminology was now, for better or worse, not something exciting and new. It was a science on its way to being institutionalized in the universities and was accepted as a tool for political reform and social engineering. It was no longer as spectacular, visual, international, threatening and oppositional as it once had been, as it was when it first gained ground in nineteenth-century Sweden. It was now embedded, intertwined and reproduced inside the Swedish establishment.

\section{BIBLIOGRAPHY}

Agge, I., Från straffrätt till kriminalvetenskap: Minneskrift utgiven av juridiska fakulteten i Stockholm vid dess femtioårsjubileum, Stockholm, Norstedt, 1957.

Andersson, R., Nilsson R., Svensk kriminalpolitik, Malmö, Liber, 2009.

Beck, N., Enrico Ferri's scientific socialism: a Marxist interpretation of Herbert Spencer's organic analogy, Journal of the history of biology, 2005, 38, 2, p. 301-325.

Becker, P., Wetzell, R. (Eds.), Criminals and their scientists: the history of criminology in international perspective, Cambridge, Cambridge University Press, 2006.

Beirne, P., Inventing criminology: essays on the rise of homo criminalis, Albany, State University of New York Press, 1993.

Charney, L., Schwartz, V. (Eds.), Cinema and the invention of modern life, Berkeley: University of California Press, 1995.

Crosland, M., Science under control: the French academy of sciences 1795-1914, New York, Cambridge University Press, 1992.

Desjardin, A., Nya läror om brott och straff, Ute och hemma, 1891, 8, p. 616-639.

Ekdahl, A., Om rättsmedicinska undersökningar rörande sinnesbeskaffenhet hos för brott tilltalade personer, diss., Lund, 1895.

Crime, Histoire \& Sociétés / Crime, History \& Societies, vol. 22, n² | 2018 
Everett-Lane, D.A., International scientific congresses, 1878-1913: community and conflict in the pursuit of knowledge, Diss., New York, Columbia University, 2004.

Ferri, E., Socialismo e scienza positiva: Darwin-Spencer-Marx, Rome, Casa editrice italiana, 1894.

Ferri, E., Den positiva straffrättsskolan”, Nordisk revy, 1896.

Ferri, E., Socialism och modern vetenskap, Stockholm, Björck \& Börjesson, 1903.

Garland, D., Punishment and welfare: a history of penal strategies, Aldershot, Gower, 1984.

Garpenhag, L., Kriminaldårar: sinnessjuka brottslingar och straffrihet i Sverige, ca 1850-1930, Diss., Uppsala, Acta Universitatis Upsaliensis, 2012.

Gibson, M., Born to crime: Cesare Lombroso and the origins of biological criminology, Westport, Praeger, 2002.

Gibson, M., Cesare Lombroso and Italian criminology: theory and politics, in Becker, P., Wetzell, R. (Eds.), Criminals and their scientists: the history of criminology in international perspective, Cambridge, Cambridge University Press, 2006.

Gibson, M., Rafter, N., Editors' Introduction, in Lombroso, C. (Ed.), Criminal man, Durham, Duke University Press, 2006.

Greenslade, W., Degeneration, culture and the novel 1880-1940, Cambridge, Cambridge University Press, 1994.

Gustafsson, T., Läkaren, döden och brottet: studier i den svenska rättsmedicinens etablering, Diss., Uppsala, Acta Universitatis Upsaliensis, 2007.

Hadenius, S., Weibull, L., Massmedier: en bok om press, radio \& TV, 8th ed., Stockholm, Bonnier, 2005.

Hagströmer, J., Om förhållandet mellan lagstiftning och vetenskap på den svenska straffrättens område, Tidsskrift for Rettsvitenskap, 1889.

Hansson, J., Humanismens kris: bildningsideal och kulturkritik i Sverige 1848-1933, Eslöv, Brutus Östlings bokförlag Symposion, 1999.

Häthen, C., Straffrättsvetenskap och kriminalpolitik: de europeiska straffteorierna och deras betydelse för svensk strafflagstiftning 1906-1931, Diss., Lund: Lund University Press, 1990.

Hebenton, B., Jou, S., Conceptual approaches to the study of "national" traditions in criminology, International journal of law, crime and justice, 2008, 36, 2, p. 115-130.

Jonsson, K., Vid vetandets gräns: om skiljelinjen mellan naturvetenskap och metafysik i svensk kulturdebatt 1870-1920, Lund, Arkiv, 1987.

Jülich, S., Skuggor av sanning: tidig svensk radiologi och visuell kultur, Diss., Linköping, Linköpings universitet, 2002.

Jäderholm, A., Rättsläkarens uppgift i frågor om tillräknelighet, Hygiea, 1883, 2.

Kaluszynski, M., The international congresses of criminal anthropology: shaping the French and international criminological movement, 1886-1914, in Becker, P., Wetzell, R. (Eds.), Criminals and their scientists: the history of criminology in international perspective, Cambridge, Cambridge University Press, 2006.

Knepper, P., Ystehede, P.J. (Eds.), The Cesare Lombroso handbook, Abingdon, Routledge, 2013.

Kreüger, J., Studier rörande sinnessjukdomars inflytande på den kriminella tillräkneligheten, Tidskrift för lagstiftning, lagskipning och förvaltning, 1885. 
Kreüger, J., Några ord om de nyare positivistiska och socialistiska riktningarna inom kriminalrätten, Tidskrift för lagstiftning, lagskipning och förvaltning, 1886.

Kumlien, M., Uppfostran och straff: studier kring 1902 års lagstiftning om reaktioner mot ungdomsbrott, Diss., Uppsala, Uppsala universitet, 1994.

Kuukkanen, J.M., I am knowledge. Get me out of here! On localism and the universality of science, Studies in history and philosophy of science, $2011,42,4$, p. 590-601.

Leps, M.C., Apprehending the criminal: the production of deviance in nineteenth-century discourse, Durham, Duke University Press, 1992.

Leth, G., Kriminaljournalistik i historiskt perspektiv, in Gadd, P. (Ed.), Mord, blod och moral: om kriminaljournalistik. Stockholm, Carlssons, 1994.

Lindström, H., Hjärnornas kamp: psykologiska idéer och motiv i Strindbergs åttiotalsdiktning, Diss., Uppsala, Uppsala universitet, 1952.

Livingstone, D.N., Putting science in its place: geographies of scientific knowledge, Chicago, University of Chicago Press, 2003.

Lombroso, C., Religion och brott, Nordisk revy, 1896.

Mazza, A., Antropologiska och penintärkongressen i Rom, Ur dagens krönika, 1886.

Melossi, D., Controlling crime, controlling society: thinking about crime in Europe and America, Cambridge, Polity, 2008.

Melossi, D., Sozzo, M., Sparks, R., Introduction. Criminal questions: cultural embeddedness and diffusion", in Melossi, D., Sozzo, M., Sparks, R. (Eds.), Travels of the criminal question: cultural embeddedness and diffusion, Oxford, Hart Publishing, 2011.

Modéer, K.Å., Johan, C.W., Thyrén - legendarisk lundaprofessor, in Johan C. W. Thyrén: legendarisk lundaprofessor, Lund: Kulturen i Lund, 1983.

Nilsson, R., Från cellfängelse till beteendeterapi: fängelse, kriminalpolitik och vetande 1930-1980, Malmö, Égalité, 2013.

Nye, R.A., Crime, madness \& politics in modern France, Princeton, Princeton University Press, 1984.

Palmblad, E., Medicinen som samhällslära, Stockholm, Norstedts akademiska förlag, 2005.

Pasquino, P., Criminology: the birth of a special knowledge, in Burchell, G., Gordon, C., Miller, P. (Eds.), The Foucault effect: studies in governmentality, with two lectures by and an Interview with Michel Foucault, Chicago, University of Chicago Press, 1991.

Persson, M., Förnuftskampen: Vitalis Norström och idealismens kris, Stockholm, Brutus Östlings bokförlag Symposion, 1994.

Petersson Hjelm, A.C., Fängelset som välfärdsbygge, rev. ed., Stockholm, Institutet för rättshistorisk forskning, 2011.

Pick, D., Faces of degeneration: a European disorder, c.1848-c.1918, Cambridge, Cambridge University Press, 1989.

Pollack, E., En studie i medier och brott, Diss., Stockholm, Stockholms universitet, 2001.

Qvarsell, R., Utan vett och vilja: om synen på brottslighet och sinnessjukdom, Stockholm, Carlsson bokförlag, 1993. 
Radzinowicz, L., The roots of the International association of criminal law and their significance: a tribute and a re-assessment on the centenary of the IKV, Freiburg, Max-Planck-Institut für ausländisches und internationales Strafrecht, 1991.

Rafter, N., Criminal anthropology: its reception in the United States and the nature of its appeal, in Becker, P., Wetzell, R. (Eds.), Criminals and their scientists: the history of criminology in international perspective, Cambridge, Cambridge University Press, 2006.

Rafter, N., The criminal brain: understanding biological theories of crime, New York, New York University Press, 2008.

Rafter, N., “Introduction”, in Rafter, N. (Ed.), The origins of criminology: a reader, Abingdon, Routledge, 2009.

Retzius, G., Alphonse Bertillon antropometriska metod att identifiera brottslingar, Hygiea, festband, 1889.

Schuldheis, G., Om sinnessjuka fångar i Sverige under åren 1865-1894: rättsmedicinska och kliniska studier, diss., Uppsala, Uppsala universitet, 1898.

Secord, J.A., Knowledge in transit, Isis, 2004, 95, 4, p. 654-672.

Sekula, A., The body and the archive, October, 1986, 39, p. 3-64

Sighele, S., Moderna förbrytare, Nordisk revy, 1895.

Spierenburg, P., The rise of criminology in its historical context, in Knepper, P., Johansen, A. (Eds.), The Oxford handbook of the history of crime and criminal justice, New York, Oxford University Press, 2016.

Staël von Holstein, O., Nya straffrättsfrågor: del 1, Nytt juridiskt arkiv II, 1889.

Staël von Holstein, O., Nya straffrättsfrågor: del 2, Nytt juridiskt arkiv II, 1890.

Stråth, B., Sveriges historia 1830-1920, Stockholm, Norstedt, 2012.

Sundgren, F., Om brott och brottslingar: strödda kriminal-antropologiska uppsatser, Stockholm, Bonnier, 1897.

Sundell, J.O., Karl Schlyter: en biografi, Stockholm, Norstedts juridik, 1998.

Svedin, G., "En ohyra på samhällskroppen": kriminalitet, kontroll och modernisering i Sverige och Sundsvallsdistriktet under 1800- och det tidiga 1900-talet, Höör, Brutus Östlings bokförlag Symposion, 2015.

Thyrén, J., Abhandlungen aus dem Strafrechte und der Rechtsphilosophie 1: Bemerkungen zu den kriminalistischen Kausalitätstheorien, Lund, Gleerup, 1894.

Thyrén, J., Abhandlungen aus dem Strafrechte und der Rechtsphilosophie 2: Über Dolus und Culpa, T. 1, Über die Möglichkeit einer Grenze zwischen Dolus und bewusster Culpa, Lund, Gleerup, 1896.

Thyrén, J., Om affliktiva straff, Appendix. II, in Forhandlinger paa niende nordiske juristmøde 1899, Kristiania, 1900.

Thyrén, J., Straffrättens allmänna grunder, Lund, Gleerup, 1907.

Thyrén, J., Principerna för en strafflagsreform. 1: Straffets sociala uppgift, Lund, Gleerup, 1910.

Villa, R., Lombroso and his school: from criminal anthropology to medicine and law, in Knepper, P., Ystehede, P.J. (Eds.), The Cesare Lombroso handbook, Abingdon, Routledge, 2013. 
Wetzell, R.F., Inventing the criminal: a history of German criminology, 1880-1945, Chapel Hill, University of North Carolina Press, 2000.

Wiener, M.J., Reconstructing the criminal: culture, law and policy in England, 1830-1914, Cambridge, Cambridge University Press, 1990.

Witt-Brattström, E., Dekadensens kön: Ola Hansson och Laura Marholm, Stockholm, Norstedt, 2007.

Wolff, L., En blick från medicinsk ståndpunkt på den moderna kriminalantropologin, Hygiea, $1897,59$.

Ystehede, P.J., In the twilight of good and evil: Cesare Lombroso and the criminological imagination, Saarbrücken, VDM Verlag, 2008.

\section{NOTES}

1. During recent decades, the history of Lombroso and his school has received interest from historians and criminologists alike. See, for example, Gibson (2002); Gibson and Rafter (2006); Rafter (2008); Ystehede (2008); Knepper and Ystehede (2013). The author acknowledges that "positivist" could be used to describe a whole range of criminological practices and traditions but, in this article, the term "positivist" refers exclusively to the school formed around Lombroso.

2. On locality of knowledge, see, for example, Livingstone (2003). For a critical discussion, see Kukkanen (2011) and Secord (2004).

3. Kuukkanen (2011, p. 590).

4. Gibson (2006); Melossi (2008); Villa (2013).

5. For issues concerning investigation of "national traditions" in the history of criminology, see Hebenton and Jou (2008).

6. Melossi et al. (2011, p. 4). For the travel of criminology in the late nineteenth century, see Rafter (2009) and the contributions in Becker and Wetzell (2006), especially Rafter (2006).

7. Secord (2004, p. 664).

8. See Leps (1992); Melossi (2008); Spierenburg (2016); Wiener (1990).

9. On the genesis of Lombroso's theories, see Gibson and Rafter (2006); Rafter (2008) and Villa (2013).

10. Gibson (2006) and Villa (2013).

11. On the critique from the French school, see Beirne (1993); Leps (1992); Nye (1984). On the congresses of criminal anthropology, see Kaluzynski (2006).

12. Radzinowicz (1991).

13. Radzinowicz (1991, p. 71). See also Pasquino (1991).

14. On the influence of von Liszt in Sweden, see Häthén (1990).

15. On the political situation and political discourse in Sweden in the late nineteenth century, see Stråth (2012) and Svedin (2015).

16. Stråth (2012).

17. For the context of criminology, see Rafter (2008). For the Swedish discussion, see Jonsson (1987); Persson (1994); Hansson (1999).

18. Ferri even incorporated Spencer into his scientific socialism; see Beck (2005). In regard to interest in criminology in Sweden, it is telling that the only book of Ferri translated into Swedish was Socialismo e scienza positiva: Darwin-Spencer-Marx- Ferri (1894). For the Swedish translation, see Ferri (1903). 
19. On the role of the press in the creation of a public sphere in Sweden, see Hadenius and Weibull (2005). On Swedish crime journalism, see Pollack (2001) and Leth (1994). On crime problems at the end of the nineteenth century generally, see Svedin (2015).

20. Kaluzynski (2006). On the role of the International Congresses of Criminal Anthropology in establishing criminology as a science, see also Everett-Lane (2004) and Nye (1984).

21. Crosland (1992).

22. See, for example, "Kriminalistkongressen", Svenska Dagbladet, 13 August 1892 and "Kriminalistkongressen”, Svenska Dagbladet, 15 August 1892. See also Mazza (1886).

23. See, for example, "Från kongresserna i Paris (Bref till Aftonbladet)", Aftonbladet, 24 August 1889.

24. On the growing visual culture in Sweden in the late 19th century, see Jülich (2002). For an international perspective, see Charney and Schwartz (1995). On the visuality of criminal anthropology, see Rafter (2006).

25. "En 'antropologisk-kriminalistisk' kongress", Aftonbladet, 5 August 1885; "Antropologiska kriminal-kongressen i Rom", Aftonbladet, 30 november 1885.

26. "Om identifiering af brottslingar", Aftonbladet, 8 October 1889; "Ett besök hos doktor Bertillon, i polisprefekturen i Paris, Del 1", Aftonbladet, 8 October 1889; “Ett besök hos doktor Bertillon, i polisprefekturen i Paris, Del 2", Aftonbladet, 10 October 1889; "Ett besök hos doktor Bertillon, i polisprefekturen i Paris, Del 3", Aftonbladet, 12 October 1889. The story was also published in a medical journal in Retzius (1889). On Bertillon and his science, see Sekula (1986).

27. See, for example, "Från kongresserna i Paris (Bref till Aftonbladet)", Aftonbladet, 24 August 1889 and "En mottagning hos prins Roland Bonaparte (Bref till Aftonbladet)", Aftonbladet, 27 August 1889.

28. See, for example, "Kriminalistkongressen i Kristiania", Stockholms Dagblad, 28 August 1891.

29. “Göteborg”, Göteborgs Handels- och Sjöfartstidning, 29 August 1891.

30. "Juridik och vetenskap", Arbetet, 1 September 1891.Translation by this author, original: "ett vackert uttryck för de moderna, mänskligare rättsprinciperna".

31. See, for example, "Förbrytarens väsen", Aftonbladet, 24 April 1892.

32. See, for example, "Förbrytaremenniskan", Nya dagligt allehanda, 11 October 1890.

33. For a discussion in a popular forum by a scientific authority, see Desjardin (1891). For a critique in a medical journal, see Wolff (1897).

34. "En socialistisk professor", Svenska Dagbladet, 25 September 1893; "En krokodil inför rätta", Aftonbladet, 21 September 1896 and "Kyssens uppkomst”, Svenska Dagbladet, 13 February 1894.

35. "De nya rörelserna på straffrättens område", Aftonbladet, 25 October 1892; "Brott och straff", Göteborgs aftonblad, 24 January 1891 and "Ur veckans krönika", Svenska Dagbladet, 5 September 1892.

36. Lombroso (1896); Ferri (1896); Sighele (1895).

37. Lindström (1952) and Qvarsell (1993, p. 143-146). For international perspectives on the same period, see Greenslade (1994) and Pick (1989).

38. Witt-Brattström (2007, p. 83-85).

39. On the rule of public servants in nineteenth-century Sweden, see Stråth (2012, p. 67-70).

40. "Brott och straff", Göteborgs Aftonblad, 24 January 1891.

41. See Persson (1994) and Hansson (1999) for the conservative critique of science. For critique of criminology, see "Ur veckans krönika", Svenska Dagbladet, 15 August 1892 and the lectures of Frans von Schéele: “Äro brottslingar tillräkneliga”, Svenska Dagbladet, 9 April 1892 and "Brott och straff”, Göteborgs aftonblad, 24 January 1891. On the radicals' embrace of positivist criminology, see "Om den moderna kriminalpsykologien", Aftonbladet, 7 January 1891.

42. Qvarsell (1993) and Gustafsson (2007). See also Palmblad (2005).

43. Qvarsell (1993) and Garpenhag (2012).

44. This is best articulated in Jäderholm (1883). 
45. Wolff (1897).

46. Ekdahl (1895, p. 28); translation by this author; original: "Jag vet också, att mången vid första påseendet tro sig igenfinna Lombroso's lära uti mit ofvan förda räsonemang."

47. Schuldheis (1898, p. 189-190).

48. The text that stands out in this regard is Wolff (1897).

49. For the German context, see Wetzell (2000).

50. The establishment of a modern penal policy in Sweden is discussed in Andersson and Nilsson (2009). See also Häthen (1990); Qvarsell (1993); Kumlien (1994). On penal welfarism in general, see Garland (1984).

51. See, for example, Kreüger (1885) and Kreüger (1886). On the reception of modern theories of penal law in the Swedish legal establishment, see Häthen (1990).

52. See especially Hagströmer (1889).

53. Sundgren (1897) and "Kriminalpolitiska experiment på svensk botten", Aftonbladet, 22 January 1895.

54. See especially Hagströmer (1889).

55. On an early discussion of IKV in Swedish legal circles, see Staël von Holstein (1889) and Staël von Holstein (1890). On the Swedish engagement in the early years of IKV, see Agge (1957) and Häthen (1990).

56. See Thyrén (1894); Thyrén (1896); Thyrén (1900). On the role of Thyrén in Swedish jurisprudence and Swedish penal policy, see Häthen (1990) and Modéer (1983). In time the old guard eventually died off. In 1910 all three of Sweden's chairs in penal law were occupied by scholars who to a greater or lesser extent accepted the modern theories of penal law.

57. Häthen (1990) and Kumlien (1994). This quest for compromise between scientific and legal perspectives endured into the twentieth century. See especially Thyrén (1907) and Thyrén (1910). 58. Nilsson 2013; Pettersson Hjelm 2011; Andersson and Nilsson 2009; Sundell 1998; Qvarsell 1993.

\section{ABSTRACTS}

This article considers how, and to what extent, the ideas and theories developed by Lombrosian, Positivist criminology were received and came to be embedded in Sweden. It demonstrates first the way in which new criminological ideas were widely reported in the press and by other means in nineteenth-century Sweden, partly due to Lombroso's own celebrity but also partly due to public interest in the proceedings of international congresses. It then goes on to analyze the way in which ideas of "the born criminal" and the social bases of crime came to be seen, by some, as a challenge to the existing political order. Finally, the article considers the impact of Positivist criminology in the spheres of medical discourse and jurisprudence.

Cet article examine par quelles voies et avec quel succès les idées et les théories développées par la criminologie positiviste lombrosienne ont été reçues et acclimatées en Suède. Il démontre comment les nouvelles idées criminologiques ont d'abord été largement diffusées par la presse, en raison notamment de la célébrité de Lombroso, mais également au travers de l'intérêt du public pour les travaux des congrès internationaux. Il analyse ensuite la manière dont les idées de « criminel né » et les fondements sociaux de la criminalité ont été perçus par certains comme une remise en question de l'ordre politique existant. Enfin, l'article revient sur l'impact de la criminologie positiviste sur le discours médical et la jurisprudence. 


\section{AUTHOR}

\section{ANDERS PEDERSSON}

Department of Literature, History of Ideas, and Religion

University of Gothenburg

anders.pedersson[at]lir.gu.se 